\title{
Arte, educação e sociedade em György Lukács e na pedagogia histórico-crítica
}

\author{
Mariana de Cássia Assumpção \\ Newton Duarte \\ Universidade Estadual Paulista
}

\section{Resumo}

Objetivo deste artigo é mostrar que tanto a arte como a educação escolar estabelecem uma relação indireta e mediada com a sociedade, ao passo que incidem diretamente na formação dos indivíduos. György Lukács, em seus estudos estéticos, mostra que as obras de arte agem sobre a subjetividade dos indivíduos, desenvolvendo sua sensibilidade e enriquecendo suas formas de percepção da realidade. Dermeval Saviani, em seus estudos pedagógicos, mostra que o papel mediador da educação escolar, no interior da totalidade da prática social, promove a humanização dos indivíduos. Como exemplo das relações mediadas entre as produções culturais e a prática social, apresentamos uma breve análise da peça Antígona, de Sófocles.

Palavras-chave: Arte. Educação escolar. Sociedade.

\section{Art, Education and Society in György Lukács and Historical-Critical Pedagogy}

\begin{abstract}
The aim of this paper is to show that art and school education have an indirect and mediated relation with the society while affect directly on the development of the individuals. György Lukács shows in his aesthetics studies that art works on the subjectivity of individuals, promoting the development of their sensibility and their forms of perception of reality. Dermeval Saviani shows in his pedagogical studies that the mediating role of school education, inside the totality of social practice, promotes the humanization of the individuals. It is presented a brief analyses of the play Antigone of Sophocles with the aim to exemplifying the mediated nature of relations between the cultural productions and the social practice.

Keywords: Art. School education. Society.
\end{abstract}


Arte, educação e sociedade em György Lukács e na pedagogia histórico-crítica

\section{El arte, la educación y la sociedad en György Lukács y en la pedagogía histórico-crítica}

\section{Resumen}

El objetivo de este trabajo es mostrar que el arte y la educación escolar tienen una relación indirecta y mediatizada con la sociedad, mientras que afectan directamente al desarrollo de los individuos. György Lukács muestra en sus estudios de estética que el arte trabaja en la subjetividad de los individuos, promoviendo el desarrollo de su sensibilidad y de sus formas de percepción de la realidad. Dermeval Saviani muestra en sus estudios pedagógicos que el papel mediador de la educación escolar, dentro de la totalidad de la práctica social, promueve la humanización de los individuos. Se presenta un breve análisis de la obra Antígona de Sófocles con el objetivo de ejemplificar la naturaleza mediada de las relaciones entre las producciones culturales y la práctica social.

Palabras clave: Arte. Educación escolar. Sociedad.

\section{Introdução}

Neste artigo procuramos mostrar, fundamentando-nos em György Lukács e Dermeval Saviani, que tanto a arte como a educação escolar estabelecem uma relação indireta e mediada com a sociedade, ao passo que incidem diretamente na formação dos indivíduos.

Uma das questões mais importantes para a compreensão da função da educação escolar é a das relações entre a prática pedagógica e a prática social em sua totalidade. No livro Escola e Democracia, Saviani (2009, p. 66) conceitua a educação como uma "[... ] atividade mediadora no seio da prática social global".

A pedagogia histórico-crítica considera como um elemento primordial na educação escolar o papel desempenhado pelo professor na sua função de transmitir, a cada aluno, as produções culturais que, tendo sido desenvolvidas pelo gênero humano no decorrer da história social, possam se constituir em elementos formadores da humanidade nos indivíduos. O processo de reconhecimento da cultura como produção imanente à atividade humana, desencadeia o desenvolvimento da consciência, sem o qual não ocorre a humanização dos indivíduos em suas formas mais desenvolvidas e plenas. 
A prática social está sempre inserida no processo de continuidade da história social ao longo do qual têm sido produzidas necessidades cada vez mais complexas que expandem as possibilidades de atuação dos seres humanos. Esse processo se estende às novas gerações que precisam incorporar o legado cultural construído ao longo da história. Não se trata, portanto, de mera passagem, de mão em mão, de uma massa inerte de produtos sem vida, mas de uma constante revitalização da atividade objetivada na cultura. Como argumenta Duarte:

A apropriação dos resultados das atividades humanas, para que eles se incorporem a novas atividades, não se reduz ao ato físico da posse (ato mecânico), da mesma forma que não se reduz à propriedade privada, que é a forma capitalista de apropriação. Trata-se de algo muito mais rico e complexo: a atividade humana que existe no objeto como propriedade em repouso, como latência, é trazida novamente à vida ao se incorporar à atividade dos indivíduos. [...]. Esse acionamento da efetividade humana é exatamente o fato de que o indivíduo, para incorporar à sua individualidade a riqueza existente na cultura material e ideativa, precisa colocar em movimento a atividade humana que está posta na cultura numa condição de contínuo intercâmbio entre latência e efetivação (DUARTE 2016, p. 54).

A arte, assim como a ciência e a filosofia, constitui uma das esferas da produção não material, cujas relações com as necessidades humanas não se caracterizam por uma linearidade do tipo: necessidade - produção do objeto que satisfaz essa necessidade. O objeto artístico é igualmente um produtor de necessidades que pode impulsionar o indivíduo para além das fronteiras delineadas pela vida cotidiana.

Lukács (1966) analisa a arte como uma forma específica de reflexo da realidade. As maneiras pelas quais a arte reflete a realidade são distintas das formas pelas quais essa realidade se reflete na consciência cotidiana e na ciência.

A ciência seria "desantropomorfizadora", ou seja, procuraria produzir um conhecimento da realidade despido, o mais possível, de distorções acarretadas pelo antropomorfismo, ao passo que a arte procuraria refletir a realidade humana de forma igualmente humana e, nesse sentido, a arte seria conscientemente antropomórfica, fazendo da existência histórica da humanidade seu 
Arte, educação e sociedade em György Lukács e na pedagogia histórico-crítica

objeto primeiro e último. Esse caráter antropomórfico da arte relaciona-se, na estética lukacsiana, ao processo pelo qual os seres humanos reconhecem a realidade social como resultado de sua própria atividade.

Uma propriedade específica às grandes obras artísticas está na evocação de sentimentos no sujeito receptor, provocando uma intensificação, um aprofundamento de vivências que, possivelmente, o indivíduo não experimentaria em suas experiências cotidianas.

A obra de arte é uma forma de expressão da subjetividade humana, mas, nesse processo, ocorre a superação da particularidade da personalidade, tanto do artista quando do sujeito receptor, colocando-se ambas as subjetividades em um nível mais elevado de relacionamento consciente com o gênero humano.

A arte como uma esfera superior de criação humana vem a estabelecer relações indiretas com as necessidades práticas do cotidiano. Essa ideia está presente ao longo dos estudos do filósofo húngaro György Lukács sobre a arte e, especialmente, quando ele contrapõe os objetos artísticos ao que ele denominou como retórica forense ou publicitária, que visa obter um efeito prático e imediato em termos do comportamento daqueles que dela se apropriam, com o objetivo de convencê-los sobre alguma ideia.

A arte autêntica, entretanto, elabora os problemas humanos de uma maneira própria, que não é aquela da cotidianidade, não tendo por objetivo produzir resultados imediatos. Mas, ao alcançar resoluções propriamente estéticas para as grandes questões humanas, a arte acaba por enriquecer o mundo humano, agindo indiretamente sobre as questões cotidianas.

Seguindo esse princípio, evidenciamos algumas implicações para o campo educacional. Da mesma forma que, no âmbito estético, as relações com a vida não são diretas, também as relações entre a prática educativa e a prática social não se reduzem a aspectos pragmáticos e imediatos. Os conhecimentos artísticos, filosóficos e científicos ensinados na escola não têm uma finalidade prática direta, contudo, precisam ser organizados para tornar mais rica a visão de mundo dos sujeitos. Trata-se, pois, do processo caracterizado por Saviani como passagem do senso comum à consciência filosófica:

[...] a passagem do senso comum à consciência filosófica é necessária para situar a educação numa perspectiva revolucionária. Com efeito, é essa a única maneira de converte-la em instrumento 
que possibilite aos membros das camadas populares a passagem da condição de 'classe em si' para a condição de 'classe para si'. Ora, sem a formação da consciência de classe não existe organização e sem organização não é possível a transformação revolucionária da sociedade (SAVIANI, 2007, p. 7).

$\bigcirc$ aprofundamento nesse tema nos permitiu compreender melhor o papel da escola, esclarecendo que não cabe a ela a tarefa de transformar a realidade, sendo também indireto e mediado o seu efeito sobre a sociedade. Por meio da transmissão do saber sistematizado a escola altera qualitativamente a concepção de mundo dos alunos.

A análise dessas relações indiretas entre a arte e a vida dos indivíduos e entre a educação e a totalidade da prática social foi objeto da dissertação de mestrado de Assumpção (2014), que foi elaborada como parte de um conjunto de estudos vinculados à pesquisa desenvolvida por Duarte (2010) sobre o tema Arte e formação humana em Lukács e Vigotski. As considerações apresentadas neste artigo apoiam-se nesses estudos prévios.

\section{Princípios fundamentais da arte em György Lukács}

Os estudos estéticos de György Lukács (1995-1971) e os pressupostos do materialismo histórico-dialético apontam que toda a produção social está alicerçada na atividade de trabalho. $O$ trabalho pode ser compreendido, nessa perspectiva teórica, como o intercâmbio entre o ser humano e a natureza que propiciou o conhecimento sobre a realidade, ou seja, tornou possível a edificação do mundo da cultura e resultou também em mudanças qualitativas, tanto na realidade objetiva quanto no próprio ser humano.

Duarte (2013) resume esta ideia ao destacar que a produção dos meios de satisfação das necessidades básicas de existência levou a uma dupla humanização, tanto da realidade exterior como dos próprios seres humanos. Ao mesmo tempo em que os seres humanos se apropriam da natureza, eles também se objetivam nos produtos de sua atividade transformadora.

No processo de intercâmbio com a natureza, o ser humano foi, aos poucos, produzindo os meios de satisfação de suas necessidades. Essa produção dos meios carrega em si mesma um grande salto qualitativo que distinguiu os seres humanos dos animais. Em primeiro lugar porque aí estava a gênese 
Arte, educação e sociedade em György Lukács e na pedagogia histórico-crítica

do caráter teleológico da atividade humana, já que a produção de um instrumento, por mais primitivo que seja, requer a antecipação mental do resultado pretendido, tanto em termos do instrumento que se espera produzir, como dos usos que se espera que ele tenha. Em segundo lugar, a produção de meios da satisfação de necessidades dá ensejo ao nascimento de novas necessidades, gerando-se, dessa forma, uma dialética entre capacidades e necessidades que não se interrompe enquanto existir a humanidade (DUARTE, 2013, p. 25-35). Em terceiro lugar, a produção de instrumentos vem acompanhada da produção da linguagem e de formas de organização coletiva humana, ou seja, trata-se do processo de autoprodução do ser humano na condição de ser sociocultural.

Sabe-se, entretanto, que nos alvores do desenvolvimento humano, a atividade de trabalho estava diretamente ligada à satisfação de necessidades elementares, vinculada à garantia da sobrevivência dos indivíduos. Com efeito, ao satisfazer as necessidades básicas, o ser humano engendrou um processo de criação de novas necessidades cada vez mais elaboradas, as quais não se restringiam à vida material, mas estavam relacionadas às elaborações de cunho teórico e abstrato que se cristalizaram nas esferas da ciência, da arte, da filosofia e da política.

174 Afirmar que a arte se desenvolveu a partir do trabalho implica reconhecer sua gênese seu caráter imanente, fazendo com que a própria existência da arte seja para os seres humanos um testemunho de que a realidade sociocultural é obra da própria humanidade.

As obras de arte também possuiriam, segundo Lukács, o poder de provocar nas pessoas experiências afetivas e cognoscitivas que ultrapassam os limites do pragmatismo e do imediatismo da vida cotidiana. Aliás, Lukács entende que ao exercer seu efeito propriamente estético, a obra de arte estaria também agindo de maneira formativa sobre os sujeitos:

A arte opera diretamente sobre o sujeito humano; o reflexo da realidade objetiva, o reflexo dos homens sociais em suas relações recíprocas, no seu intercambio social com a natureza, é um elemento de mediação, ainda que indispensável; é simplesmente um meio para provocar este crescimento do sujeito (LUKÁCS, 1970, p. 274).

caráter evocador e formador da arte promove, ao mesmo tempo, um processo gradual de desfetichização da realidade humana, uma vez que o 
objeto estético deve promover uma "sacudida" na subjetividade. Pela percepção do conteúdo e da forma artísticos o passado se faz presente, o receptor consegue interpretar a obra de arte suplantando o fetichismo generalizado na vida cotidiana alienada (DUARTE, 2009).

ponto no qual acontece esse momentâneo rompimento com a alienação denomina-se catarse. $\bigcirc$ filósofo húngaro analisa a catarse como um processo estético e ético que caracteriza o efeito da obra de arte sobre o indivíduo. Nesse sentido, ele mostra que para alcançá-la o indivíduo precisa "[...] se elevar acima de sua singularidade, ao menos enquanto dure essa viva relação com um mundo, portanto, com a representação estética do mundo real" (LUKÁCS, 1967, p. 476).

estudioso húngaro, em sua obra estética, sintetiza os traços essenciais do conceito de catarse destacando que se trata de "[...] uma ruptura com a imagem cotidiana de mundo, as ideias e os sentimentos costumeiros relativos aos homens, aos seus destinos, aos motivos que os movem: porém uma ruptura que reconduz a um mundo melhor entendido" (LUKÁCS, 1967, p. 571). É importante ressaltar essa noção de catarse como um processo que se estende pela relação do indivíduo com as obras de arte e com os gêneros artísticos. Por mais intensos que sejam os efeitos de uma obra sobre o indivíduo, a catarse nunca se esgota.

Para compreendermos com maior clareza os efeitos da arte sobre a subjetividade dos indivíduos tomemos como exemplo uma obra largamente citada por Lukács em seu compêndio estético, qual seja, a tragédia grega Antígona escrita por Sófocles (444 a.C.). Inicialmente elaboramos uma síntese do seu enredo para, em seguida, compreendermos que a função principal da arte é agir sobre o indivíduo.

\section{A Antígona de Sófocles: uma obra modelar}

A obra de Sófocles (2003) se remete à antiguidade clássica na qual cultuavam-se vários deuses. A arte representa as ideias, convicções e valores de um momento determinado, porém, ao mesmo tempo, a obra de arte extrapola essa fronteira e, no interior da necessidade histórica que a engendrou, produz um movimento que evidencia o que há de mais humano no contexto 
Arte, educação e sociedade em György Lukács e na pedagogia histórico-crítica

retratado. A peça Antígona traz, por assim dizer, o caráter imanente que constitui o núcleo de uma obra de arte genuína.

Os personagens que integram a tragédia grega de Sófocles são: Antígona, Ismênia, Policine, Etéocles (os quatro filhos de Édipo com Jocasta); Creonte (irmão de Jocasta); Hémon (filho de Creonte); Eurídice, lesposa de Creonte); Tirésias (sábio de Tebas); um enviado, um guarda, um mensageiro e os velhos tebanos. O cenário da peça é a cidade-estado de Tebas, localizada na Grécia antiga.

Édipo, o rei de Tebas, tinha dois filhos, Polinice, Etéocles e duas filhas, Ismênia e a protagonista, Antígona. Quando da morte do rei, seus dois filhos entraram em combate para ocupar o trono que ficara vazio. Porém, deste conflito resultou a morte de ambos. Diante de tal situação, o irmão de Édipo, Creonte que também pleiteava seu lugar ao trono, subiu ao poder.

Etéocles, um dos filhos de Édipo, quando do embate pelo poder de Tebas, colocou-se a favor do tio que agora assumira o trono, ao passo que Polinice posicionou-se como o maior rival de seu tio. Tendo os dois sobrinhos mortos, Creonte ofereceu um enterro digno, prestando todas as honrarias ao sobrinho Eteócles que the apoiou durante toda a vida. Já Polinice, que havia negado auxílio ao tio, em vez de ser enterrado tal como o irmão teve, a mando de Creonte, seu corpo jogado às aves. Além disso, o rei de Tebas ordenou que seria condenado à morte quem ousasse prover um funeral ao seu sobrinho.

Antígona considerava injusta a atitude de Creonte, pois, segundo ela, tais deliberações demostravam que seu tio tinha a pretensão de se colocar acima dos desígnios dos deuses, ao arbitrar sobre o direito dos indivíduos em terem ou não uma cerimônia fúnebre. Nessa cultura o funeral era um rito de passagem muito estimado, como uma preparação para a chegada a outro mundo.

Antígona, movida por seu amor fraternal e por seu respeito ao que considerava valores acima dos poderes do rei. Desobedece, então, a ordem de seu tio e enterra o irmão com a dignidade que ela julgava merecida. Ao descobrir a traição da sobrinha, Creonte the pergunta qual o motivo que a fez transgredir as leis impostas, mesmo sabendo das consequências desastrosas desse ato. $\bigcirc$ diálogo assim se passa:

- Creonte: Foi então um desafio bem premeditado? 
- Antígona: Tu o compreendeste. A tua lei não é a lei dos deuses; apenas o capricho ocasional de um homem. Não acredito que tua proclamação tenha tal força que possa substituir as leis não escritas dos costumes e os estatutos infalíveis dos deuses. Porque essas não são leis de hoje, nem de ontem, mas de todos os tempos: ninguém sabe quando apareceram. Não, eu não iria arriscar o castigo dos deuses para satisfazer o orgulho de um pobre rei. Eu sei que vou morrer, não vou? Mesmo sem teu decreto. E se morrer antes do tempo, aceito isso como uma vantagem. Quando se vive como eu, em meio a tantas adversidades, a morte prematura é um grande prêmio. Morrer mais cedo não é uma amargura, amargura seria deixar abandonado o corpo de um irmão. E se disseres que ajo como louca eu te respondo que só sou louca na razão de um louco (SÓFOCLES, 2003, p. 25-26).

Aqui fica evidente como a obra de arte reflete uma época especifica com suas contradições e dilemas sociais. Nesse período predominava uma forte relação com os pressupostos religiosos, de veneração aos diferentes deuses. Todavia, percebe-se que com seus desígnios, Creonte rompeu também com os preceitos éticos e morais de sua época. Isso porque ele lançou mão de sua autoridade para se vingar, negando ao sobrinho uma cerimônia importante e valorizada na época. Para Antígona a lei divina sobrepunha-se a leis dos homens e sendo estas últimas, em verdade, cruéis e injustas, não havia motivos para ela temer a morte que se anunciava em função da sua desobediência.

Antígona é, portanto, condenada e mesmo os pedidos de clemência do povo de Tebas e, em especial de seu próprio filho Hémon, que nutria amores por Antígona, não fizerem com que Creonte retrocedesse de sua decisão. Vê-se nesse trecho a revolta do rei de Tebas por ver seu filho colocar-se em defesa de Antígona, evidenciando-se a questão da justiça e da moral presente na obra de Sófocles:

- Creonte: Miserável! Combate o próprio pai. Em meu lar só tenho alimentado inimigos que se aliam a outros inimigos em todas as esquinas da cidade. Se não conseguem me afastar do trono é só porque têm uma ambição sem causa. Um para fugir à luta, outro para escapar ao fisco, aquele por um pedaço de terra, este por uma mulher, todos são contra mim. Não te pedi, nem te permito que me fales como um deles. Fala como meu filho, a quem tão cedo confiei minhas melhores tropas. 
Arte, educação e sociedade em György Lukács e na pedagogia histórico-crítica

- Hémon: Mais do que como teu filho, falo pela verdade. Repito: toda a cidade aprova a ação de Antígona, mesmo os que condenam Polinices.

- Creonte: É fraqueza fazer menos do que eu fiz. Não basta apenas destruir o traidor. É preciso que seja exposto à execração para que fique o princípio os que se deixam corromper são abatidos. Se a minha mão tremer estou perdido. Se a minha voz hesitar, cairão sobre mim. E tu, que ignoras tudo ou quase tudo, pedes-me que escute a voz do povo. Essa voz que gagueja frases sem sentido. Para fertilizar o solo é necessário força. Não se pergunta ao solo se deseja a lâmina do arado.

- Hémon: Uma ordem generosa produz muito mais frutos. Para os que governam, saber esquecer é salutar.

- Creonte: Para os governados ainda é mais. Por que não esqueces essa por quem tanto te expões? Largaste as tropas para interpelar-me. Defendes mais a ela que a Tebas.

- Hémon: Defendo apenas a justiça (SOFOCLÉS, 2003, p. 40-41, grifos no original).

A execução de Antígona pelo governo de Creonte, a rigor, não foi necessária, pois ela suicidou-se. Desolado pelos acontecimentos e principalmente pela morte de sua amada, Hémon também interrompe sua vida. Nessa altura da tragédia grega pode-se dizer que a obra de Sófocles, evidencia como os dilemas, os personagens e o cenário que movem a trama, propiciam uma vivência estética que abre o caminho à percepção e, sobretudo, à tomada de consciência de conflitos morais vividos não apenas na antiguidade, mas que se fazem presentes em muitos momentos da história humana. Em um sentido mais amplo, essa obra se refere a "[...] um problema humano e moral que, em sua contraditoriedade, atravessa toda a história da sociedade de classes" (LUKÁCS, 1970, p. 221 ).

Portanto, o critério necessário para se definir uma obra de arte genuína é o quanto a dinâmica entre essência e aparência e a contradição posta entre o conteúdo e a forma artística provocam no sujeito um aguçamento de emoções em um movimento que tende a romper, momentaneamente, com a alienação do cotidiano favorecendo uma compreensão mais digna da realidade em que se vive. 
Essa peça teatral sintetiza e intensifica uma situação que, apesar de se vincular a um período remoto da história, ainda hoje se faz presente na vida dos indivíduos, ou seja, a obra traz à cena o acirramento de conflitos que perpassam pelo tema da justiça e da moral.

Outro aspecto importante refere-se ao fato da referida obra se enquadrar no gênero trágico. Aristóteles foi o primeiro a classificar as obras de arte em geral, sendo que o gênero trágico abrangia as obras que tratavam dos grandes dilemas humanos que foram, desde a antiguidade, os principais temas explorados pelo pensamento filosófico.

enredo trágico, ao destacar os grandes dilemas humanos, concentra grandes possibilidades de promover a desfetichização do indivíduo, isto é, de mostrar o mundo como resultado da ação humana, "Para uma síntese autêntica do que a arte produziu no curso de milênios, a tragédia é precisamente a demonstração mais expressiva e adequada e a autoconsumação mais plástica, intensa e terrena do ser humano" (LUKÁCS, 1967, p. 437).

Ainda sobre o gênero trágico, é importante dizer que:

Conteúdo e a conformação trágica se inscrevem na unidade entre interno e externo. A tragédia consegue converter uma coisa em outra quando transforma algo que é interno em externo; por exemplo, o destino, que é fruto do mundo circundante, acaba se configurando como algo interno. Na tragédia subsiste uma relação de afinidade entre o phatos do herói trágico e o destino (SANTOS NETO, 2013, p. 62, grifo do autor).

A tragédia constitui-se, então, como o gênero artístico no qual a especificidade do objeto estético apresenta-se em sua forma mais desenvolvida. Isso porque, uma característica específica do gênero trágico é seu caráter representativo no que tange a não aceitação da realidade existente. $\bigcirc$ herói da tragédia apresenta-se como um indivíduo que quebra as regras sociais, que sofre as consequências de seus atos orientados pela busca de um objetivo mais amplo que extrapola, portanto, a sua própria individualidade. $\bigcirc$ sujeito receptor, ao se deparar com uma peça como a Antígona, é convidado a viver os dilemas da personagem e a vivenciar a inevitabilidade dos desdobramentos das decisões e escolhas.

Ainda que o conflito desta peça de Sófocles, muito embora se estruture tendo como polos o ser humano e os deuses, as decisões são tomadas 
Arte, educação e sociedade em György Lukács e na pedagogia histórico-crítica

pelos seres humanos e eles as levam às últimas consequências. A conotação divina aparece aí como uma forma de representação dos valores e das ideias predominantes em determinada época. Embora o conflito apareça na forma de oposição entre a vontade humana (do rei) e as normas divinas, a essência da trama revela conflitos entre valores essencialmente humanos.

Uma interessante questão que inevitavelmente emerge ao se discutir a estética refere-se ao efeito que, até hoje, as obras antigas proporcionam. Essa comoção e esse abalo, produzidos por obras elaboradas em períodos históricos distantes do atual, estão relacionados ao fato da arte incorporar à memória da humanidade aspectos da vida humana que surgem em determinado momento histórico e se incorporam à vida humana como questões de valor fundamental.

$\bigcirc$ filósofo húngaro interpreta essa caraterística das obras de arte, ancorando-se na ideia marxiana de que a antiguidade grega tem uma forma de expressão que pode ser comparada à infância da humanidade. "Cada homem tem certa consciência, uma certa recordação da própria infância [...]. Na medida em que a arte é também recordação do passado da humanidade, o processo de conversação do passado na arte é igualmente um processo extremamente complexo" (KOFLER; ABENDROTH; HOLZ, 1969, p. 29-30).

Assim, como a infância individual incorpora-se à personalidade adulta, a infância da humanidade se incorpora ao patrimônio cultural universal. Por meio dos estudos históricos, pode-se conhecer o passado da humanidade e por meio da arte pode-se vivenciá-lo como se fizesse parte da vida de cada um de nós.

As grandes obras de arte ultrapassam os limites do tempo e se tornam clássicas por retratarem as fases do humano e, nessa direção, caracterizam-se como a memória da humanidade. Ao mostrar o ser humano como o responsável pela sua existência e como um ser social, as obras de arte condensam as experiências afetivas e certamente continuarão a exercer seu papel sobre os indivíduos das gerações futuras.

\section{As relações indiretas e mediadas entre arte e sociedade}

Ao analisar a obra de Sófocles a partir dos estudos lukacsianos demostramos que a função da arte é a de atuar sobre o indivíduo. 
A arte opera diretamente sobre o sujeito humano; o reflexo da realidade objetiva, o reflexo dos homens sociais em suas relações recíprocas, no seu intercambio social com a natureza, é um elemento de mediação, ainda que indispensável; é simplesmente um meio para provocar este crescimento do sujeito (LUKÁCS, 1970, p. 274).

Se a arte está diretamente voltada ao sujeito, ela relaciona-se, portanto, de modo indireto e mediado com a prática social. Um traço essencial da estética lukacsiana é a tentativa de explicar que os efeitos desencadeados pela arte não se verificam direta nem imediatamente na prática social, uma vez que tais efeitos se instalam no âmbito do processo formativo dos indivíduos.

[... ] a atividade estética do espírito tem por condição liminar a interrupção de todo elo direto com a prática. $\bigcirc$ fenômeno é muito mais verificável numa época mais tardia, por exemplo, na Antiguidade, em que a autonomização das diversas formas espirituais é muito mais sensível. Um discurso no fórum, uma atividade retórica ou escritural qualquer visam persuadir e estão, portanto, inevitavelmente ligadas a uma finalidade prática. Em oposição, a tragédia alça o acontecimento contingente do sofrimento humano ao nível de um drama da espécie humana e fá-lo atingir o plano da universalidade (TERTULIAN, 2008, p. 208-209).

A diferença entre a atividade estética e a atividade retórica está no fato de que nesta última trata-se de desencadear "[... algo imediatamente prático, sem ter que precisar sempre se os meios apelam diretamente à imediatez" (LUKÁCS, 1966, p. 229). Já na arte "[...] o que é acentuado é justamente o efeito imediato conseguido pelos efeitos de formatação; em troca, sua passagem ao prático - o efeito educador da arte - [...] é algo muito complicado e desigualmente mediado".

Um dos requisitos para que se alcance essa possibilidade educadora e formadora, aproximando-se dos níveis de maior desenvolvimento do gênero humano, tanto no campo científico como estético, é fazer com que o indivíduo se afaste momentaneamente do fluxo da prática social, se desprenda da imediatez, da espontaneidade e do pragmatismo do cotidiano, atingindo, desse modo, um meio homogêneo. Este meio homogêneo se estrutura, como ratifica Lukács (1966a, p. 329), a partir de uma "[...] suspensão temporária de toda a finalidade prática". 
Arte, educação e sociedade em György Lukács e na pedagogia histórico-crítica

O efeito da obra de arte se dá em termos das relações entre a subjetividade dos indivíduos e sua condição de pertencimento ao gênero humano e, portanto, a obra artística pode influenciar a vida cotidiana, porém, de modo indireto. Apesar de não se verificarem de imediato, os efeitos estéticos ocorrem e são, sobretudo, humanizadores e enriquecedores da visão de mundo dos indivíduos.

As expressões artísticas podem se incorporar à vida cotidiana de forma tão ou mais extensiva que as elaborações científicas, mas tal incorporação não ocorre, no mais das vezes, no sentido do atendimento de finalidades práticas, mas sim no sentido da produção de efeitos sobre a subjetividade dos seres humanos. As artes:

[...] suscitam nos seres humanos paixões, dão a estes determinados sentimentos, direções etc., graças aos quais os homens se tornam capazes de intervir praticamente na vida social, de lutar a favor ou contra determinados fatos sociais [...]. Em todo caso também é visível que a generalização das atividades surgidas pela suspensão do interesse prático imediato no estético não tem como objeto a realidade em si, senão o mundo humano, o mundo tal como existe objetivamente em sua relação com o ser humano (LUKÁCS, 1966a, p. 333-334).

$\bigcirc$ reflexo estético, já por seu caráter antropomorfizador, evidencia que a sua finalidade, em primeiro lugar, é a de incidir na subjetividade, e em segundo lugar e consequentemente, na prática social.

Se, pois, a obra exerce um efeito evocador, esse efeito tem que conter - consciente ou inconsciente direta ou talvez, muito mediatamente - o despertar de sua tomada de partido. Mas a força e a profundidade reais da evocação artística se dirigem acima de tudo à interioridade do indivíduo: o que ocorre acima de tudo é o despertar de novas vivências no indivíduo, as quais ampliam e aprofundam sua imagem de si mesmo, do mundo com o qual tem que se defrontar no sentido mais amplo da palavra (LUKÁCS, 1966a, p. 334).

Lukács (1966) considera a arte como uma das formas de reflexo da realidade objetiva, sem que isso signifique, entretanto, que a obra expresse direta e necessariamente a concepção de sociedade do sujeito criador. Sua subjetividade é, sem dúvida, decisiva no ato de produção artística e se objetiva 
na obra. Mas essa subjetividade, como captação artística da realidade, pode ser mais rica e desenvolvida do que as ideias que o artista, como indivíduo, adota sobre a realidade social e até mesmo sobre as relações entre arte e prática social.

Nesse sentido, pode inclusive haver uma contradição entre as posições que o indivíduo artista toma em relação à sociedade e as posições que estão contidas nas obras que ele produz. Essa reelaboração, pela subjetividade do artista, do material coletado da realidade, produz uma reconfiguração que promove uma ampliação e uma intensificação de emoções e ideias no indivíduo receptor. A arte, portanto, reflete dialeticamente a realidade mostrando um determinado posicionamento em face dos problemas sociais.

A prática artística não é neutra. Porém, as relações entre história e estética não são relações de causa e efeito. A arte possui também uma autonomia relativa no que tange às determinações sociais. Não se pode afirmar que uma obra de arte será autêntica apenas quando abordar temas relacionados à luta de classes, à desigualdade presente na sociedade capitalista, à exploração do trabalho. Ao se debruçar sobre outros aspectos da vida humana, captando o seu núcleo, a obra de arte indiretamente contribui para o engajamento ético-político, para a reflexão crítica da realidade, pois atua sobre o indivíduo da prática, ampliando a sua consciência e desenvolvendo sua subjetividade.

filósofo húngaro explica o porquê de artistas alinhados à classe dominante de uma época, expressarem em suas obras de arte uma concepção de mundo oposta aos seus próprios posicionamentos políticos.

Trata-se, antes de mais nada, daquela honestidade estética incorruptível, isenta de qualquer vaidade, própria dos escritores e artistas verdadeiramente grandes. Para eles, a realidade, tal como ela é, tal como se revelou em sua essência após pesquisas cansativas e aprofundadas, está acima de todos os seus desejos pessoais mais caros e mais íntimos. A honestidade do grande artista consiste precisamente no fato de que, quando a evolução de um personagem entra em contradição com as concepções ilusórias em função das quais ele se engendrara na fantasia do escritor, este o deixa desenvolver-se livremente até suas últimas consequências, sem se perturbar com o fato de que suas mais profundas convicções viram fumaça por estarem em contradição com a autêntica e profunda dialética da realidade. Tal é a honestidade que podemos constatar e estudar em Cervantes, em Balzac, em Tolstói (LUKÁCS, 2009, p. 1131. 
Arte, educação e sociedade em György Lukács e na pedagogia histórico-crítica

As relações entre o artista e sua obra não devem ser analisadas apenas sob o ponto de vista do momento histórico da criação (LUKÁCS, 2009). Limitar-se ao contexto social e às convicções do sujeito criador é simplificar as possibilidades que a arte encerra. No centro a partir do qual o estudo estético deve se desenrolar, está a própria obra de arte.

Um bom artista, mesmo que não tenha plena consciência disso, é um artista realista, pois, de alguma forma, ele se propõe a investigar a realidade e a exprimi-la, captando suas contradições essenciais, promovendo uma compreensão mais profunda da dinâmica e do movimento do real.

A estética lukacsiana opõe-se à retórica e à arte panfletária estritamente pragmática, segundo a qual o artista deveria, para que sua criação fosse considerada autêntica, expressar diretamente a sua opinião sobre determinado tema. Tal recurso, muito utilizado pelos meios de comunicação de massa na sociedade capitalista, tem servido como estratégia na luta ideológica.

Lukács (1966b, p. 522) afirma que esse conjunto de expressões artísticas "[...] orienta-se simplesmente ao homem inteiro situado na vida prática cotidiana, com objetivo de movê-lo diretamente a uma tomada de posição prática imediata". Esta pseudo-arte fica presa ao utilitarismo social, reiterando a imediatez da vida cotidiana e, nesse sentido, não desperta uma vivência estética, não se preocupa com a catarse nem pretende desenvolver uma formação humana integral, pois, à revelia dos pressupostos artísticos, visa um resultado imediato na prática social.

Por outro lado, a estética lukacsiana também se opõe às tendências abstratas que desvinculam a estética do seu fundamento histórico-social entendendo a criação e recepção artísticas como atividades totalmente subjetivas, como necessidades desinteressadas e estranhas às conexões sociais. Tal concepção entende que a arte possui um fim em si mesmo, existindo tão somente como uma forma abstrata de representação. Um exemplo dessa vertente é a concepção de "arte pela arte".

O efeito da arte, que ocorre no âmbito da evocação de vivências que ultrapassam o cotidiano, contribui para o desenvolvimento de comportamentos novos e qualitativamente diferentes nos indivíduos, ampliando as possibilidades de ação sobre a prática social e não se reduz a uma expressão somente abstrata e subjetiva que não produz efeitos significativos nos indivíduos. 
Tertulian (2008, p. 1 18) afirma que Lukács reitera, sem hesitação, que a função do objeto estético, a qual se orienta não para a existência real (pragmática) do objeto como tal, mas para "[...] o seu reflexo na consciência; que o comportamento estético exige que se destaque o objeto do contexto empírico-pragmático e que se prenda à sua reflexão na consciência".

Em linhas gerais a representação artística da realidade implica dois movimentos essenciais. $\bigcirc$ primeiro deles se refere a já mencionada suspensão das finalidades diretas e imediatamente práticas e o segundo, que é consequência do primeiro, refere-se ao despertar de vivências que possibilitam uma compreensão mais acurada dos elementos e fenômenos do mundo.

Essas são algumas diferenças entre a arte e os demais modos de reflexo da realidade. $\bigcirc$ estético se caracteriza por sua força evocativa, por promover a desfetichização, gerando transformações na subjetividade. Vê-se, portanto, a dialeticidade presente na forma artística de reflexo da realidade. É primordial ressaltar quão indireta é a efetividade da arte no que diz respeito a um processo de transformação radical da sociedade. Seu núcleo gira em torno às subjetividades, suscitando determinados afetos, elevando a percepção das contradições da realidade a um nível que culmina na apreensão, pelos indivíduos, da essência historicamente construída da humanidade.

Em primeiro plano, as expressões artísticas contribuem para o desenvolvimento sensível e intelectual de cada sujeito a partir da apropriação, em um nível mais elevado, das contradições da história humana e por consequência, favorece as condições para a tomada de consciência da possibilidade de modificação de si mesmo e da realidade.

A arte, assim como todas as formas de atividade humana nas sociedades marcadas pela luta de classes, está subordinada aos processos alienantes, contudo ela pode incidir indiretamente sobre a base das relações sociais de produção, na medida em que se volta a desfetichização da realidade humana refletida na consciência dos indivíduos que atuam na prática social. Antígona, Hamlet e Don Quixote são personagens da literatura que "[...] podem exercer uma forte influência sobre as possibilidades de ação" (KOFLER; ABENDROTH; HOLZ, 1969, p. 36). 


\section{As relações mediadas entre educação escolar e sociedade}

A prática educativa é o momento de afastamento relativo da prática social. Momento este necessário para que os indivíduos possam elaborar questionamentos e compreender melhor a realidade em que vivem. Seria incorreto afirmar, contudo, que a prática educativa não estabelece relação com o restante da prática social, alegando que enquanto se estuda não se realiza uma atividade diretamente material e de intervenção direta na realidade.

A natureza da atividade de estudo é a de ser uma atividade que não gera resultados propriamente materiais, mas também se deve salientar que a ação humana sobre a realidade ocorre pela unidade entre a atividade material e a mental numa dinâmica indissociável. Afirmar que a educação não se vincula ao restante da prática social por não estar imediatamente relacionada a ações de cunho prático efetivo é preterir as mediações e a dialeticidade existente entre os fenômenos sociais. É preciso ver a educação como um processo no qual crianças, adolescentes e jovens devem ter acesso a um ensino de qualidade que promova a ampliação das consciências e das subjetividades. Nessa direção, ressalvamos que:

[... ] a alteração objetiva da prática só pode dar-se a partir da nossa condição de agentes sociais ativos, reais. A educação, portanto, não transforma de modo direto e imediato e sim de modo indireto e mediado, isto é, agindo sobre os sujeitos da prática (SAVIANI, 2009, p. 651.

À primeira vista poderia parecer que a pedagogia histórico-crítica, ao defender a educação escolar e a transmissão sistemática do conhecimento científico, artístico e filosófico em suas formas mais elaboradas, estivesse adotando uma concepção do conhecimento como algo que teria valor em si mesmo. Isso colocaria essa pedagogia em desacordo com seu fundamento.

Na escola, muitas vezes, precisamos aprender a controlar o nosso corpo, ficando sentados por um tempo para nos concentrarmos nos estudos e nos apropriarmos de conhecimentos com elevado grau de complexidade e sistematização. Ficar sentado e parado na sala de aula não rompe com as relações entre a educação escolar e o restante da prática social nem retira da escola suas relações com a sociedade em seu todo. Apenas salienta-se o papel específico da educação escolar que é o de socializar a apropriação dos 
conhecimentos científicos, artísticos e filosóficos promovendo, dessa maneira, a humanização dos indivíduos.

A educação escolar é atividade privilegiada para se provocar nos sujeitos essa carência, essa necessidade de se apropriar das produções culturais humanas, ampliando-se, dessa forma, a visão de mundo dos alunos. Percebe-se aí a dialética entre objetivo e subjetivo. A apropriação da riqueza objetiva produzida pela atividade humana por meio da transmissão dos conteúdos científicos, artísticos e filosóficos na escola, proporciona o enriquecimento das subjetividades.

A veracidade do conhecimento humano é posta pela prática, mas isso não estabelece de forma alguma um vínculo imediato entre a teoria e a prática. A prática é o critério de verdade, mas a prática social deve ser entendida como um processo histórico de desenvolvimento da humanidade, da qual a prática cotidiana é tão somente uma de suas partes. Identificar prática social com prática cotidiana é tomar a parte pelo todo.

Nesse sentido, a pedagogia histórico-crítica não desconsidera que a prática é o critério de verdade da teoria, mas entende que as relações entre teoria e prática devem ser analisadas à luz da totalidade histórica da prática social humana se não quisermos endossar o discurso pragmático e imediatista que é largamente difundido pelas pedagogias hegemônicas na atualidade como, por exemplo, a pedagogia das competências, o método de ensino baseado na resolução de problemas e a pedagogia de projetos.

\section{Considerações finais}

Ao longo deste artigo verificamos que, desde os primórdios do desenvolvimento, os seres humanos estabeleceram mediações. Com a atividade de trabalho, ou seja, com a produção dos meios que satisfazem as suas necessidades, os seres humanos modificaram dialeticamente tanto a si mesmos como à natureza, em um processo de complexificação contínua. A complexidade da criação humana passou dos elementos que satisfaziam as necessidades vinculadas estritamente à sobrevivência e à vida material para os elementos de ordem não material, sendo a arte um exemplo desse tipo de produção.

A arte autentica é um tipo de objetivação humana que transmite a humanidade aos indivíduos, no sentido que aponta para o gênero humano, 
Arte, educação e sociedade em György Lukács e na pedagogia histórico-crítica

ou seja, ela não se reduz aos aspectos mais corriqueiros e cotidianos ligados à reprodução da vida do indivíduo e da sociedade. A arte é uma forma de reflexo da realidade objetiva que tem como função principal, tal como a educação escolar, incidir sobre a constituição das subjetividades.

A arte deve provocar nos sujeitos sentimentos que não se conectam imediatamente à cotidianidade, embora nela produzam efeitos ao contribuir para a desfetichização dos indivíduos acerca da realidade humana. Uma arte verdadeiramente grande é aquela que faz os indivíduos tomarem consciência dos conflitos humanos, possibilitando assim um entendimento mais acurado do contexto em que se vive. Além disso, a criação e fruição artísticas não se desenvolvem naturalmente, mas sim dependem de um processo educativo.

Lukács esclarece a função evocadora e desfetichizadora da arte, afirmando que ela é uma forma específica de reflexo da realidade objetiva e que a forma artística de reflexo do real é, sobretudo, uma forma que a exprime como um produto humano. Ou seja, a arte possibilita a humanização e a elevação da consciência humano-genérica dos indivíduos. A arte tem a função de provocar reações emocionais diretamente no âmbito da subjetividade das pessoas, agindo assim, indiretamente sobre a realidade objetiva. $\bigcirc$ momento da 188 catarse seria o ponto alto da relação entre o sujeito e a obra de arte. Momento este em que há uma transformação na forma como o sujeito compreende a realidade.

A educação é analisada pela pedagogia histórico-crítica como uma atividade não material que estabelece uma relação indireta com a sociedade. Esta característica da educação escolar é fundamental para o desenvolvimento dos indivíduos, na medida em que os dota das ferramentas indispensáveis à compreensão das raízes dos problemas sociais. A pedagogia histórico-crítica afirma o papel da escola em educar as consciências. A escola tem em potencial essa possibilidade de, ao ensinar, fazer com que os indivíduos possam interferir na realidade no sentido de romper com o modelo vigente.

A função da arte e da educação é atuar objetivamente na consciência, ou melhor, na subjetividade dos indivíduos. A catarse depende necessariamente da educação estética para atingir êxito. Um sujeito educado artisticamente e que possui uma sensibilidade apurada tem enormes possibilidades de, diante de uma obra de arte autêntica, captar seus elementos, analisá-los de modo crítico. Em última instância a catarse não terá resultados positivos se o sujeito for 
insensível, se a sua subjetividade não estiver desenvolvida o suficiente para sentir as contradições e emoções que a obra potencialmente venha a despertar.

\section{Referências}

ASSUMPÇÃO, Mariana de Cássia. A prática social na pedagogia histórico-crítica e as relações entre arte e vida em Lukács e Vigotski. 2014. 172f. Dissertação (Mestrado em Educação Escolar) - Programa de Pós-Graduação em Educação Escolar, Universidade Estadual Paulista, Araraquara, 2014.

DUARTE, Newton. Arte e educação contra o fetichismo generalizado na sociabilidade contemporânea. Perspectiva, Florianópolis, v. 27, n. 2, p. 461-479, jul./dez. 2009.

Arte e formação humana em Lukács e Vigotski. In: DUARTE, Newton; DELLA FONTE, Sandra Soares. Arte, conhecimento e paixão na formação humana. Campinas: Autores Associados, 2010.

A individualidade para-si: contribuições a uma teoria histórico-crítica da formação do indivíduo. 3. ed. rev. Campinas: Autores Associados, 2013.

Os conteúdos escolares e a ressurreição dos mortos. Campinas: Autores Associados, 2016.

KOFLER, Leo; ABENDROTH, Wolfgang; HOLZ, Hans Heinz. Conversando com Lukács. Rio de Janeiro: Paz e Terra, 1969.

LUKÁCS, Georg. Estetica I: la peculiaridad de lo estetico. Cuestiones previas y de princípio. Tradução Manuel Sacristan. Barcelona: Grijalbo, 1966 (v. 1).

Estetica I: la peculiaridad de lo estetico. Problemas de la mímesis. Manuel Sacristan. Barcelona: Grijalbo, 1966a (v. 2).

LUKÁCS, Georg. Estetica I: la peculiaridad de lo estetico. Cuestiones liminares de lo estético. Manuel Sacristan. Barcelona: Grijalbo, 1967. (v. 4).

Introdução a uma estética marxista. 2. ed. Tradução Carlos Nelson Coutinho e Leandro Konder. Rio de Janeiro: Civilização Brasileira, 1970.

Arte e sociedade: escritos estéticos de 1932-1967. Tradução Carlos Nelson Coutinho e José Paulo Netto. Rio de Janeiro: Editora da UFRJ, 2009.

SANTOS NETO, Artur Bispo dos. Estética e ética na perspectiva materialista. São Paulo: Instituto Lukács, 2013. 
SAVIANI, Dermeval. Educação: do senso comum à consciência filosófica. 17. ed. rev. Campinas: Autores Associados, 2007.

SAVIANI, Dermeval. Escola e democracia. 41 . ed. Campinas: Autores Associados, 2009.

SÓfOClES. Antígona. 6. ed. São Paulo: Paz e Terra, 2003.

TERTULIAN, Nicolas. Georg Lukács: etapas de seu pensamento estético. São Paulo: Editora UNESP, 2008.

Profa. Ms. Mariana de Cássia Assumpção Universidade Estadual Paulista

Faculdade de Ciências e Letras Araraquara Programa de Pós-Graduação em Educação Escolar Grupo de pesquisa "Estudos Marxistas em Educação" E-mail | mca.assumpcao@gmail.com

Prof. Dr. Newton Duarte Universidade Estadual Paulista

Faculdade de Ciências e Letras Araraquara Programa de Pós-Graduação em Educação Escolar Grupo de pesquisa "Estudos Marxistas em Educação" E-mail | newton@fclar.unesp.br

Recebido 7 mar. 2017 Aceito 18 abr. 2017 